\title{
Peningkatan Kapasitas Kader Muhammadiyah Dalam Penanganan Gejala Pada Lansia Dengan Penyakit Kronik
}

\author{
Erna Rochmawati ${ }^{1}$ \\ 1. Program Magister Keperawatan, Universitas Muhammadiyah Yogyakarta \\ Jl.Brawijaya, Kasihan, Bantul, Daerah Istimewa Yogyakarta \\ Email: erna.rochmawati@umy.ac.id \\ DOI: 10.18196/ppm.32.202
}

\begin{abstract}
Abstrak
Latar belakang: individu lanjut usia dengan penyakit degeneratif sering kali mengalami gejala fisik, misalnya sesak nafas, nyeri, dan gangguan nutrisi. Penatalaksanaan gejala-gejala tersebut secara sederhana dapat dilakukan di rumah, baik oleh anggota kelvarga yang merawat maupun kader kesehatan yang terlatih. Organisasi Kesehatan Dunia (WHO) menyarankan jenis perawatan yang paling tepat dikembangkan di negara berkembang seperti Indonesia adalah dengan melibatkan masyarakat, baik masyarakat langsung maupun masyarakat dalam bentuk organisasi. Muhammadiyah merupakan organisasi keagamaan terbesar di Indonesia yang memiliki peran penting dalam bidang kesehatan dan pendidikan. Kerja sama antara amal usaha di bidang pendidikan dan organisasi otonomi Muhammadiyah, misalnya Lazismu, masih sangat terbatas. Lazismu PCM Sedayu yang telah dimulai sejak November 2019 telah memiliki beberapa program, tetapi masih ada keterbatasan, khususnya kemampuan sumber daya manusia, rancangan program untuk masyarakat, dan kolaborasi dengan amal usaha Muhammadiyah terdekat. Tujuan kegiatan pengabdian masyarakat ini adalah membekali sumber daya manusia dengan pengetahuan dan kemampuan dalam menangani gejala-gejala utama yang seringkali dialami oleh lansia yang kedepannya akan dapat berperan sebagai kader muda Muhammadiyah. Metode yang digunakan dalam kegiatan ini adalah dengan memberikan pelatihan pada lima belas kader yang telah direkrut dari setiap ranting di wilayah PCM Sedayu. Pelatihan dilakukan secara terstruktur, meliputi materi pengetahuan dan demonstrasi penatalaksanaan gejala sesak nafas, nyeri, dan gangguan nutrisi. Pelatihan dilakukan selama $3 \times 50$ menit. Pengukuran dilakukan dengan pre dan post test untuk pengetahuan dan redemonstrasi ketrampilan dilakukan dengan teknik relaksasi nafas dalam. Hasilnya ialah terdapat peningkatan pengetahuan kader untuk penanganan gejala pada lansia, dari 71.53 menjadi 81.66. Semua kader dapat melakukan redemonstrasi dengan baik, yaitu untuk teknik nafas dalam dan pengkajian nyeri dengan baik. Kesimpulannya adalah bahwa kegiatan pengabdian masyarakat ini dapat meningkatkan kemampuan kader. Kegiatan selanjutnya dapat difokuskan untuk mempertahankan kemampuan yang sudah dimiliki dan praktik kader ke lansia.
\end{abstract}

Kata Kunci: kader; lanjut usia; pelatihan; penatalaksanaan gejala

\section{Pendahuluan}

Salah satu tujuan dari Sustainable Development Goals (SDGs) adalah setiap individu berbagai usia memiliki kesehatan dan kesejahteraan yang baik. Namun, seiring dengan meningkatnya harapan hidup jumlah individu berusia lanjut yang memiliki penyakit degeneratif juga meningkat, baik global maupun di Indonesia, khususnya Yogyakarta. Jumlah lansia meningkat hampir dua kali lipat dalam kurun waktu lima puluh tahun terakhir, yakni menjadi 25 juta pada tahun 2019. Dari jumlah tersebut mayoritas adalah lansia muda (60-69 tahun), yaitu sekitar $63.82 \%$ serta lansia madya dan tua sebesar 36.18\%. Daerah Istimewa Yogyakarta merupakan provinsi dengan struktur penduduk lansia tertinggi di Indonesia, yakni sebesar 15.4\% (Susilo et al., 2019).

Dari sisi kesehatan, separuh lansia mengalami keluhan kesehatan selama sebulan terakhir. Penelitian dari Zhao et al di Haikou Cina mengidentifikasi jika 31.7\% lansia memiliki satu penyakit kronis (Zhao et al., 2018). Penyakit kronis yang paling banyak diderita oleh lansia tersebut adalah hipertensi, Diabetes Mellitus, penyakit paru obstruksi kronik dan stroke. Di Indonesia sendiri, hasil survei yang dilakukan oleh Badan Pusat Statistik pada tahun 2019 menunjukkan satu dari empat lansia sakit dalam sebulan terakhir. Kesadaran lansia terhadap keluhan kesehatan yang dideritanya cukup tinggi. Mayoritas lansia mengobati keluhan kesehatannya, baik dengan mengobati sendiri maupun berobat jalan $(96,46$ persen) (Susilo et al., 2019).

Dampak dari penyakit kronik yang dialami lansia adalah timbulnya kecacatan dan penurunan kemampuan dalam aktivitas sehari-hari. Hal ini menimbulkan dampak dari segi psikologis, kesulitan dalam mobilitas, fungsi kognitif yang buruk, jatuh dan insiden, luka dan cedera, kekurangan gizi, dan masalah komunikasi (Maresova et al., 2019). Untuk meminimalkan 
konsekuensi penuaan, beberapa area memerlukan perhatian lebih, seperti pendidikan dan pelatihan; alat teknologi; dukungan pemerintah dan sistem kesejahteraan; diagnosis dini kekurangan gizi, gangguan kognitif, dan penyakit lainnya; solusi komunikasi; solusi mobilitas; dan kontribusi sosial (Maresova et al., 2019).

Dibutuhkan perhatian yang cukup tinggi dari seluruh elemen masyarakat terkait hal ini karena lansia yang tinggal sendiri membutuhkan dukungan dari lingkungan sekitar mereka mengingat hidup mereka lebih berisiko, terlebih pada lansia perempuan yang cenderung termarginalkan. (Susilo et al., 2019)

Individu lanjut usia dengan penyakit degeneratif seringkali mengalami gejala fisik, misalnya sesak nafas, nyeri, dan gangguan nutrisi (Maresova et al., 2019). Penatalaksanaan gejala-gejala tersebut secara sederhana dapat dilakukan di rumah, baik oleh anggota keluarga yang merawat maupun kader kesehatan yang terlatih. Organisasi Kesehatan Dunia (WHO) menyarankan jenis perawatan yang paling tepat dikembangkan di negara berkembang seperti Indonesia adalah dengan melibatkan masyarakat, baik masyarakat langsung maupun masyarakat dalam bentuk organisasi (World Health Organization, 2014). Pelaksanaan community-based health care dapat dilaksanakan dengan dukungan dari kader kesehatan.

Kader kesehatan yang ada saat ini merupakan anggota masyarakat yang sudah diberikan pelatihan oleh tenaga kesehatan untuk memberi bantuan dalam meningkatkan perilaku hidup sehat, kesehatan ibu dan anak, serta gizi pada masyarakat (Mahendradhata et al., 2017). Namun, seiring dengan semakin kompleksnya permasalahan kesehatan yang ada di masyarakat, kader kesehatan juga perlu dibekali dengan penatalaksanaan gejala yang sering dialami oleh lansia.

Muhammadiyah merupakan organisasi keagamaan terbesar di Indonesia yang memiliki peran penting dalam bidang kesehatan dan pendidikan. Kerja sama antara amal usaha di bidang pendidikan dan organisasi otonmi Muhammadiyah, misalnya Lazismu, masih sangat terbatas. Lazismu PCM Sedayu yang telah dimulai sejak November 2019 telah memiliki beberapa program, tetapi masih ada keterbatasan, khususnya kemampuan sumber daya manusia, rancangan program untuk masyarakat, dan kolaborasi dengan amal usaha Muhammadiyah terdekat. Kegiatan pengabdian masyarakat yang berjudul peningkatan pengetahuan dan ketrampilan Angkatan Muda Muhammadiyah dalam penetalaksanan gejala pada lansia akan mengandeng Lazismu PCM Sedayu sebagai mitra. Tujuan kegiatan pengabdian masyarakat ini adalah membekali sumber daya manusia yang dengan pengetahuan dan kemampuan dalam menangani gejala-gejala utama yang seringkali dialami oleh lansia yang kedepannya akan dapat berperan sebagai kader muda Muhammadiyah.

\section{Metode Pelaksanaan}

Kegiatan pengabdian masyarakat ini merupakan pelatihan kepada kader muda Muhammadiyah. Hal ini bertujuan untuk mengetahui pengaruh pelatihan tentang penatalaksanaan gejala pada lansia terhadap peningkatan pengetahuan kader kesehatan tentang penatalaksanaan gejala pada lansia di Sedayu, Yogyakarta.

Kegiatan ini diadakan oleh Program Studi Magister Keperawatan, Program Pascasarjana, Universitas Muhammadiyah Yogyakarta dengan judul “Peningkatan Kapasitas Kader Muda Muhamamdiyah dalam Penatalaksanaan Gejala Lansia” pada bulan Maret 2020. 


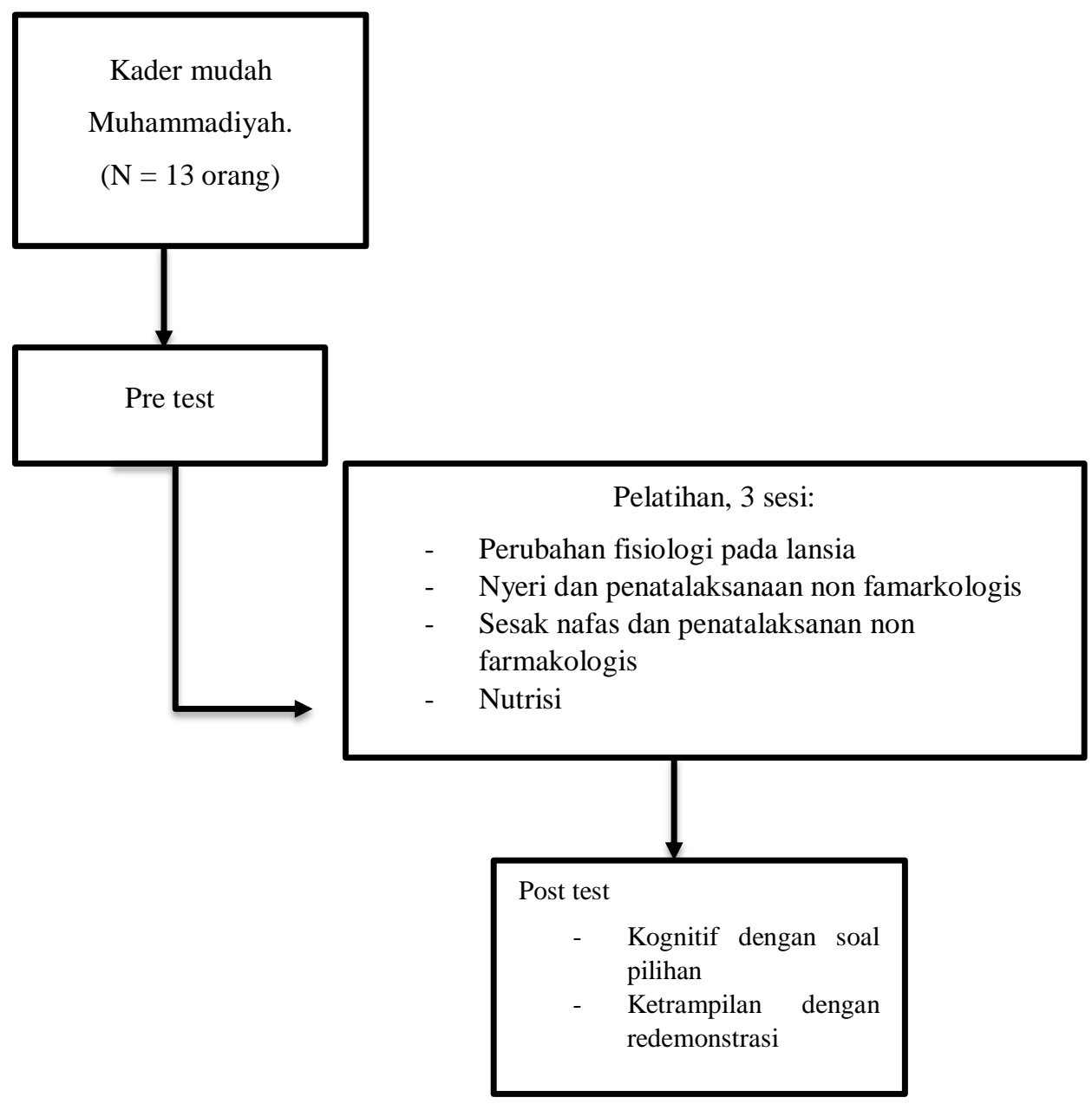

Kader yang mengikuti pelatihan dipilih dengan berdasarkan kriteria inklusi dan dilakukan di bulan Januari-Februari 2020. Kriteria inklusi adalah (i) berusia 20-50 tahun (ii) berdomisili di area Sedayu (iii) berminat menjadi kader muda Muhammadiyah. Jumlah kader yang mengikuti kegiatan diklat sebanyak tiga belas orang.

Figur pertama menunjukkan proses kegiatan pengabdian masyarakat. Kader yang sudah memberikan persetujuan untuk mengikuti pelatihan diberikan pretest. Tiga sesi pelatihan membahas perubahan yang terjadi pada lansia, penatalaksanaan nyeri, sesak nafas, dan nutrisi. Setelah pelatihan, dilakukan post test berupa soal pilihan ganda untuk mengetahui perubahan pengetahuan peserta. Soal pre test dan post test mencakup nyeri dan penatalaksanaanya, nutrisi, dan sesak nafas, serta pelaksanaanya.

Materi yang dibawakan adalah perubahan fisiologi pada lansia, nyeri dan penatalaksanan nonfarmakologi, sesak napas, penatalaksanaan nonfarmakologi, dan penatalaksanaan nutrisi pada lansia. Materi dibawakan oleh tiga narasumber dari Program Studi Magister Keperawatan, Program Pascasarjana, Universitas Muhammadiyah Yogyakarta.

\section{Hasil dan Pembahasan}

Kegiatan pelatihan untuk peningkatan kapasitas kader muda Muhammadiyah dalam penatalaksanaan gejala pada lansia berjalan dengan lanjar. Kegiatan ini dihadiri kader muda dan pengurus Lazismu Cabang Sedayu.

Tabel 1 menunjukkan karakteristik peserta pelatihan, yakni sebanyak 13 orang dengan rerata usia 36.9 tahun dan sebagian besar perempuan $(n=10,76.9 \%)$. Peserta pelatihan antusias dalam mengikuti pelatihan dari awal sampai selesai. 
Tabel 1.

Karakteristik peserta pelatihan

\begin{tabular}{|c|c|c|c|c|}
\hline No. & Karakteristik & $\begin{array}{l}\text { Frekuensi } \\
\text { (n) }\end{array}$ & $\begin{array}{l}\text { Prosentase } \\
(\%)\end{array}$ & Rerata \\
\hline 1. & Usia & & & 36.92 \\
\hline 2. & $\begin{array}{l}\text { Jenis } \\
\text { kelamin } \\
\text { Laki-laki } \\
\text { Perempuan }\end{array}$ & $\begin{array}{l}3 \\
10\end{array}$ & $\begin{array}{l}76.9 \\
23.1\end{array}$ & \\
\hline
\end{tabular}

Pelatihan dilakukan dengan memberikan materi di power point dan dengan memberikan modul untuk semua peserta. Modul berisi lebih detil mengenai perubahan pada usia lanjut serta langkah-langkah pengurangan nyeri dan sesak napas yang dapat dilakukan di rumah. Modul didesain dengan kalimat yang sederhana dan tidak terlalu banyak tulisan sehingga diharapkan tidak membosankan saat dibaca. Selain itu, modul juga berisi gambar-gambar untuk memudahkan peserta dalam memahami materi yang disampaikan. Pada pelatihan peserta, terlihat antusias mendengarkan materi yang diberikan. Saat sesi tanya jawab, beberapa peserta bertanya mengenai materi sekaligus terkait dengan pengalaman dalam merawat lansia.

Saat proses demonstrasi penatalaksanaan nyeri dan sesak napas nonfarmakologis, semua peserta pelatihan aktif memerhatikan. Setelah itu, semua peserta melakukan teknik napas dalam untuk mengurangi nyeri dan teknik napas cuping hidung yang dapat dilakukan saat terjadi sesak napas. Semua peserta terlihat antusias dalam melakukan redemonstrasi.

Pada kegiatan pelatihan ini, dilakukan evaluasi dengan mengukur nilai pra dan pascakegiatan untuk mengetahui perubahan tingkat pengetahuan pemahaman sebelum dan sesudah pelatihan (tabel 2).

\section{Tabel 2. Tingkat pengetahuan sebelum dan sesudah pelatihan}

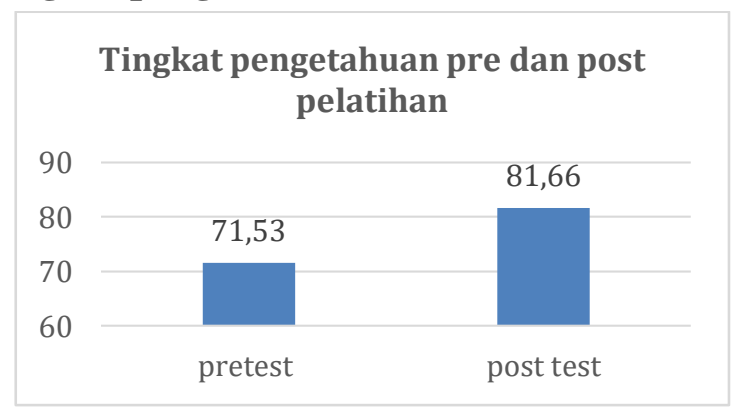

Tabel 2 menunjukkan adanya peningkatan pengetahuan kader terkait dengan penatalasaknaan gejala pada lansia. Rerata skor sebelum diberikan pelatihan adalah 71.53 dan meningkat menjadi 81.6 setelah diberikan pelatihan. Pengukuran dilakukan langsung setelah kegiatan pelatihan selesai. Hal ini dilakukan karena pada waktu pelaksanaan kegiatan pengabdian masyarakat ini sudah masuk ke pandemi Covid-19 sehingga meminimalkan kontak langsung dengan banyak individu.

Pelatihan ini menunjukkan bahwa terjadi peningkatan, baik pengetahuan maupun keterampilan kader muda setelah dilakukan pelatihan. Beberapa kader muda Muhammadiyah merasa sudah melakukan hal-hal yang berhubungan penatalaksanaan gejala nyeri, sesak napas, dan peningkatan nutrisi. Namun, baru mengetahui bahwa hal tersebut merupakan salah satu cara penatalaksanaan gejala pada lansia setelah mendapatkan pelatihan.

Peningkatan pengetahuan ini sejalan dengan kegiatan pelatihan yang sebelumnya pernah dilakukan (Parmawati et al., 2019; Wahyuningsih et al., 2019). Proses pelatihan yang kurang lebih sama pada kegiatan ini juga dilakukan oleh Wahyunigsih dkk (Wahyuningsih et al., 2019). Dalam pelatihan tersebut diberikan materi secara langsung serta dengan memberikan modul dan leaflet untuk meningkatkan pemahaman pada kader. 
Keterampilan dalam melakukan teknik napas dalam dan teknik napas cuping hidung dapat diperagakan oleh semua kader muda Muhammadiyah dengan baik pada pelatihan ini. Antusiasme dalam mengikuti pelatihan akan mempermudah pemahaman dan kemampuan dalam memeragakan ulang keterampilan.

\section{Simpulan}

Pelatihan yang dilakukan sebanyak tiga sesi dapat meningkatkan pengetahuan kader muda Muhammadiyah dalam penatalaksanaan gejala, khususnya nyeri, sesak napas, dan perubahan nutrisi pada lansia. Pelatihan efektif dilakukan dengan memberikan materi secara langsung dan memberikan modul untuk dapat dipelajari sendiri dan dibaca ulang. Kegiatan pelatihan dapat berjalan lancar dengan adanya koordinasi dengan tim Lazismu. Pemberdayaan kader yang sudah dapat dilatih akan dapat diteruskan dengan adanya kerja sama dengan pihak penyelenggara pelatihan dan pihak Lazismu Cabang Sedayu,

\section{Ucapan Terima Kasih}

Penulis mengucapkan terima kasih kepada LP3M UMY untuk dukungan finansial pada kegiatan pengabdian masyarakat ini. Penulis juga mengucapkan terima kasih kepada pihak Lazismu Sedayu atas dukungannya sehingga kegiatan pengabdian masyarakat dapat berjalan dengan baik.

\section{Daftar Pustaka}

Mahendradhata Y, Trisnantoro L, Listyadewi S, Soewondo P, Marthias T, Harimurti P, Prawira J. The Republic of Indonesia Health System Review. Health system in Transition 2017; 7.

Maresova P, Javanmardi E, Barakovic S, Barakovic Husic J, Tomsone S, Krejcar O, Kuca K. Consequences of chronic diseases and other limitations associated with old age $-\mathrm{a}$ scoping review. BMC Public Health 2019; 19: 1431.

Parmawati I, Sandhi A, Nisman WA, Lismidiati W, Rustyaningsih A, Kholisa IK. Knowledge enhancement about pregnancy complications: Optimizing the role of high risk pregnancy prepared cadres. Journal of Community Empowerment for Health 2019; 3.

Susilo D, Harahap IE, Sinang R: Statistik penduduk lanjut usia 2019. 2019.

Wahyuningsih MSH, Nugrahaningsih DAA, Probosuseno P. Increasing knowledge about nutrition and health in the elderly and cadres in Banguntapan Village, Bantul. Journal of Community Empowerment for Health 2019; 3: 1-7.

World Health Organization. Strenghtening of palliative care as a component of integrated treatment throughout the life course. Journal of Pain and Palliative Care Pharmacotherapy 2014; 28: 130-134.

Zhao C, Wong L, Zhu Q, Yang H. Prevalence and correlates of chronic diseases in elderly population: a community-based survey in Haikou. PLoS One 2018; 13. 